\title{
Homogeneous Liquid-Liquid Extraction Method for Selective Separation and Preconcentration of Trace Amounts of Palladium
}

\author{
MOHAMMAD REZA JAMALI* , YAGHOUB ASSADI, \\ REYHANEH RAHNAMA KOZANI ${ }^{\#}$ and FARZANEH SHEMIRANI ${ }^{\S}$
}

*Department of Chemistry, Payam Noor University, Behshahr, Iran.

Department of Analytical Chemistry,

Faculty of Chemistry, Iran University of Science and Technology, Tehran, Iran.

"Department of Chemistry, Payam Noor University, Sari, Iran.

${ }^{\S}$ School of Chemistry, University College of Science,

University of Tehran, Tehran, Iran.

mr_jamali@mpnu.ac.ir

Received 25 January 2009; Accepted 20 March 2009

\begin{abstract}
A simple and effective homogeneous liquid-liquid extraction method for selective separation, preconcentration and spectrophotometric determination of palladium(II) ion was developed by using a ternary component system (water / tetrabutylammonium ion $\left(\mathrm{TBA}^{+}\right)$/ chloroform). The phase separation phenomenon occurred by an ion-pair formation of $\mathrm{TBA}^{+}$and perchlorate ion. Thio-Michler's ketone (TMK), 4, 4'-bis (dimethylamino) thiobenzophenone, was used as a complexing agent. After optimization of complexation and extraction conditions $\left([\mathrm{TMK}]=5.0 \times 10^{-5} \mathrm{~mol} \mathrm{~L}^{-1},\left[\mathrm{TBA}^{+}\right]=2.0 \times 10^{-2} \mathrm{~mol} \mathrm{~L}^{-1},\left[\mathrm{CHCl}_{3}\right]=60.0 \mu \mathrm{L},\left[\mathrm{ClO}_{4}^{-}\right]\right.$ $=2.5 \times 10^{-2} \mathrm{~mol} \mathrm{~L}^{-1}$ and $\mathrm{pH}=3.0$ ), a preconcentration factor 10 was obtained for 10 $\mathrm{mL}$ of sample. The analytical curve was linear in the range of 2-100 $\mathrm{ng} \mathrm{mL}^{-1}$ and the limit of detection was $0.4 \mathrm{ng} \mathrm{mL}^{-1}$. The relative standard deviation was $3.2 \%$ $(\mathrm{n}=10)$. Accuracy and application of the method was estimated by using test samples of natural and synthetic water spiked with different amounts of palladium(II) ion. The method is very simple and inexpensive.
\end{abstract}

Keywords: Liquid-liquid extraction, Palladium, Preconcentration, Thio-Michler's ketone (TMK).

\section{Introduction}

Palladium was used in different areas of science and technology, including coating agents, brazing alloys, petroleum, electrical industries and catalytic reactions ${ }^{1,2}$. Thus, due to its increasing 
use on one hand, and the toxicity of Pd(II) compound to mammals, fish, and higher plants on the other hand ${ }^{3}$, determination of palladium is of special interest in environmental analysis.

Because of low concentration of $\mathrm{Pd}$ in industrial $\left(\mu \mathrm{g} \mathrm{g}^{-1}\right.$ level) and environmental samples (ng $\mathrm{g}^{-1}$ level) and complexity of the matrix, elaboration and application of preconcentration / matrix separation procedures is necessary before detection of the analyte. For this purpose, systems based on liquid-liquid extraction ${ }^{4-6}$ ion exchange ${ }^{7-9}$, solid sorbent extraction $^{10-12}$, electrochemical deposition ${ }^{13,14}$, precipitation and co-precipitation ${ }^{15}$ and micellar system ${ }^{16}$ have been used.

However, these methods are typically time-consuming and labor-intensive, have multi-step procedures prone to loss of analytes and need high volumes of samples. Therefore, simple, rapid and efficient techniques that can be preformed easily are required.

Homogeneous liquid-liquid extraction is an excellent method that extracts desired solute existing in the homogeneous solution into the water-immiscible phase by each kind of phase separation phenomenon. In homogeneous liquid-liquid extraction, the initial condition (before phase separation) is homogeneous solution; namely, there is no interface between the water phase and organic solvent phase. In other words, the surface area of the interface is infinitely large initially. Accordingly, no vigorous mechanical shaking is necessary. The procedure is simple, rapid and requires only the addition of the reagents ${ }^{17}$.

The methods, which used the phase separation depends upon the temperature of the water-propylene carbonate system ${ }^{18}$ or the salt effect in the water-acetonitrile system, etc. have already been reported ${ }^{19}$.

Recently, homogeneous liquid-liquid extraction method using a ternary solvent system has been developed ${ }^{17}$ and it was applied as a simple and high-powered preconcentration for the instrumental analysis ${ }^{20-23}$. In concretely, the methods based on the $\mathrm{pH}$ dependent phase separation, which used a water / acetic acid / chloroform ternary solvent system ${ }^{20}$ and water / pyridine / ethyl chloroacetate system ${ }^{24}$ were reported. However, in these methods, the widespread application for target analytes has been limited by the inconvenient $\mathrm{pH}$ condition in extraction.

Recently, a $\mathrm{pH}$ independent phase separation phenomenon using the ion-pair formation of tetrabutylammonium ion $\left(\mathrm{TBA}^{+}\right)$and perchlorate $\left(\mathrm{ClO}_{4}^{-}\right)$in homogeneous solution (water / $\mathrm{TBA}^{+} /$chloroform) has been reported. In this method, chloroform is solvated by $\mathrm{TBA}^{+}$and dissolves in water. When $\mathrm{NaClO}_{4}$ is added to the homogeneous solution that consists of a water $/ \mathrm{TBA}^{+} /$chloroform, the salvation effect of $\mathrm{TBA}^{+}$is excluded by ion-pair formation of $\mathrm{TBA}^{+}$and $\mathrm{ClO}_{4}^{-}$. Therefore, the chloroform in homogeneous aqueous solution is postulated to form water-immiscible chloroform in aqueous solution by the phase separation ${ }^{25,26}$.

In the present work, homogeneous liquid-liquid extraction, using Thio-Michler's ketone (TMK), 4,4'-bis(dimethylamino) thiobenzophenone, as a complexing agent and water / $\mathrm{TBA}^{+} /$chloroform ternary component system, was applied to the separation and preconcentration of trace amounts of $\mathrm{Pd}(\mathrm{II})$ in natural water samples and its spectrophotometric determination.

\section{Experimental}

Absorbance measurements were carried out with a Shimadzu UV-2550 double-beam spectrophotometer and a $1 \mathrm{~mL}$ quartz cell at $518 \mathrm{~nm}\left(\lambda_{\max }\right)$. Phase separation was assisted using a centrifuge (centurion scientific Ltd model: 1020D). The $\mathrm{pH}$ of the solutions was controlled with Metrohm pH-meter model 713. 


\section{Reagents and solutions}

All reagents used were of analytical grade. Stock solution of palladium (1000 $\left.\mathrm{mg} \mathrm{L}^{-1}\right)$ was prepared by dissolving appropriate amounts of metallic Pd in aqua regia. Working solutions were prepared from the stock solution by serial dilutions with doubly distilled water.

Other reagents used were tetrabutylammonium bromid (Merck), chelating agent TMK (Merck), nitric and hydrochloric acid (Merck), sodium hydroxide and sodium perchlorate (Merck). Chloroform and ethanol were of analytical - grade from Merck.

A stock standard buffer solution, $0.1 \mathrm{~mol} \mathrm{~L}^{-1}$ was prepared by dissolving appropriate amount of sodium acetate and hydrochloric acid. The pipettes and vessels used for trace analysis were kept in $10 \%$ nitric acid for at least $24 \mathrm{~h}$ and subsequently washed four times with deionized water before use.

\section{Homogeneous liquid-liquid extraction and quantification of palladium(II)}

$10 \mathrm{~mL}$ homogeneous solution (water / $\mathrm{TBA}^{+} /$chloroform) containing analyte $\left(2-100 \mathrm{ng} \mathrm{mL}^{-1}\right)$, chloroform $(60.0 \mu \mathrm{L})$, TMK $\left(5.0 \times 10^{-5} \mathrm{~mol} \mathrm{~L}^{-1}\right), \mathrm{TBA}^{+}\left(2.0 \times 10^{-2} \mathrm{~mol} \mathrm{~L}^{-1}\right)$ and $2.0 \times 10^{-3} \mathrm{~mol} \mathrm{~L}^{-1}$ acetate buffer $(\mathrm{pH}=3.0)$ were kept in a thermostated bath at $25{ }^{\circ} \mathrm{C}$ for $5 \mathrm{~min}$. An aqueous solution of $\mathrm{NaClO}_{4}\left(2.5 \times 10^{-2} \mathrm{~mol} \mathrm{~L}^{-1}\right)$ was added and the mixture was gently shaken. The mixture was then centrifuged for $3 \mathrm{~min}$ at $4000 \mathrm{rpm}$.

The sediment phase $(50 \mu \mathrm{L})$ was separated using a $100 \mu \mathrm{L}$ micro-syringe, transferred into a spectrophotometer cell and diluted to $1 \mathrm{~mL}$ with ethanol. The palladium concentration was then determined at $518 \mathrm{~nm}$ against a reagent blank.

\section{Results and Discussion}

\section{Effect of $p H$}

The separation of metal ions by homogeneous liquid-liquid extraction involves prior formation of a complex with sufficient hydrophobicity to be extracted into the small volume of sediment phase; thus obtaining the desired preconcentration. $\mathrm{pH}$ plays an unique role on metal-chelate formation and subsequent extraction. The effect of $\mathrm{pH}$ on the extraction of palladium from water samples was studied in the $\mathrm{pH}$ ranges of 1-10. Figure 1 shows the influence of $\mathrm{pH}$ on the absorbance of the palladium complex at $518 \mathrm{~nm}$.

As can be seen, at $\mathrm{pH}=3.0$ maximum absorbance was obtained. Hence, $\mathrm{pH}=3.0$ was chosen as the working $\mathrm{pH}$ and subsequent extraction was performed in acetic acid / sodium acetate buffer solution.

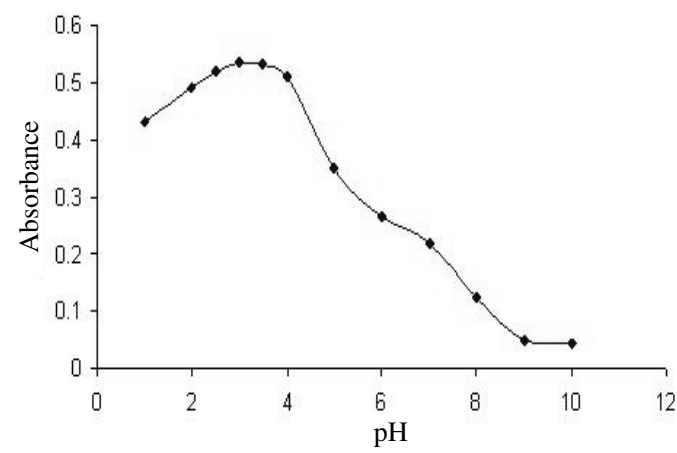

Figure 1. Effect of $\mathrm{pH}$ on the absorbance of complex. (Conditions: $P d(I I) 50.0 \mathrm{ng} \mathrm{mL}^{-1}$; TMK 5.0 $\left.\times 10^{-5} \mathrm{~mol} \mathrm{~L}^{-1} ; \mathrm{TBA}^{+} 2.0 \times 10^{-2} \mathrm{~mol} \mathrm{~L}^{-1} ; \mathrm{CHCl}_{3} 60.0 \mu \mathrm{L}_{\text {and }} \mathrm{NaClO}_{4} 2.5 \times 10^{-2} \mathrm{~mol} \mathrm{~L}^{-1}\right)$. 


\section{Effect of TMK concentration}

The effect of the concentrations of TMK on the analytical response is shown in Figure 2. The results showed that the signal increased up to a known concentration of TMK $\left(5.0 \times 10^{-6}\right.$ mol L ${ }^{-1}$ ), reaching plateau, which was considered as complete extraction. A concentration of $5.0 \times 10^{-5} \mathrm{~mol} \mathrm{~L}^{-1}$ was chosen to account for other extractable species.

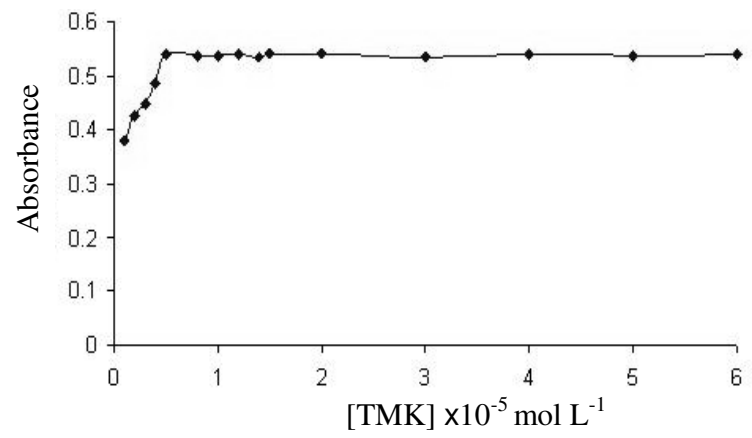

Figure 2. Effect of TMK concentration on the absorbance of the complex.

(Conditions: $\mathrm{Pd}(\mathrm{II}) 50.0 \mathrm{ng} \mathrm{mL} \mathrm{L}^{-1}$; $\mathrm{TBA}^{+} 2.0 \times 10^{-2} \mathrm{~mol} \mathrm{~L}^{-1} ; \mathrm{CHCl}_{3} 60.0 \mu \mathrm{L} ; \mathrm{NaClO}_{4} 2.5 \times 10^{-2} \mathrm{~mol} \mathrm{~L}^{-1}$ and $\mathrm{pH}=3.0)$.

\section{Effect of $\mathrm{TBA}^{+}$concentration}

In order to investigate the optimum amount of $\mathrm{TBA}^{+}$on the quantitative homogeneous liquid-liquid extraction of palladium ions using TMK, the extraction of $0.5 \mu \mathrm{g}$ of palladium from $10 \mathrm{~mL}$ of the sample solutions under the optimal experimental conditions was conducted by varying the concentration of $\mathrm{TBA}^{+}$(Figure 3 ).

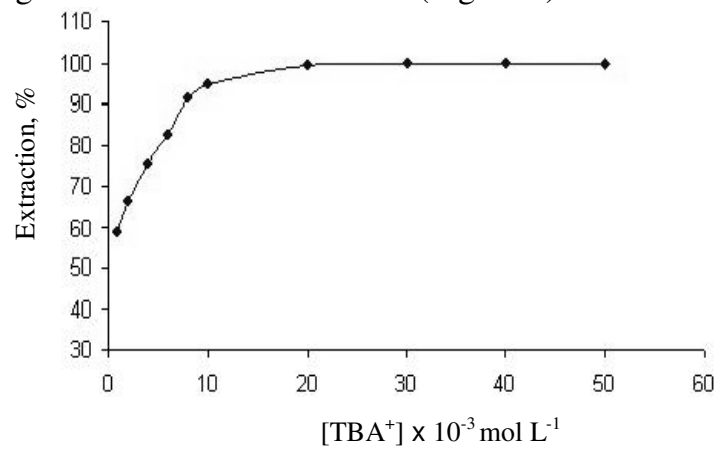

Figure 3. Effect of $\mathrm{TBA}^{+}$concentration on the extraction of palladium. (Conditions: $P d(I I)$ $50.0 \mathrm{ng} \mathrm{mL}^{-1}$; $\mathrm{TMK}^{2} .0 \times 10^{-5} \mathrm{~mol} \mathrm{~L}^{-1} ; \mathrm{CHCl}_{3} 60.0 \mu \mathrm{L} ; \mathrm{NaClO}_{4} 2.5 \times 10^{-2} \mathrm{~mol} \mathrm{~L}^{-1}$ and $\mathrm{pH}=3.0$ ).

As can be seen, the extraction of palladium is quantitative above $2.0 \times 10^{-2} \mathrm{~mol} \mathrm{~L}^{-1}$ of $\mathrm{TBA}^{+}$. Hence, subsequent homogeneous liquid-liquid extraction experiments were carried out with $2.0 \times 10^{-2} \mathrm{~mol} \mathrm{~L}^{-1}$ of $\mathrm{TBA}^{+}$. At lower concentration, the system remains two phases and the extraction is not quantitative.

\section{Effect of $\mathrm{ClO}_{4}^{-}$concentration}

In order to determine the concentration of $\mathrm{ClO}_{4}{ }^{-}$for quantitative recoveries, the extraction of $0.5 \mu \mathrm{g}$ of palladium from $10 \mathrm{~mL}$ of the sample solutions under the optimal experimental conditions was conducted by varying the concentration of $\mathrm{ClO}_{4}^{-}$(Figure 4). 


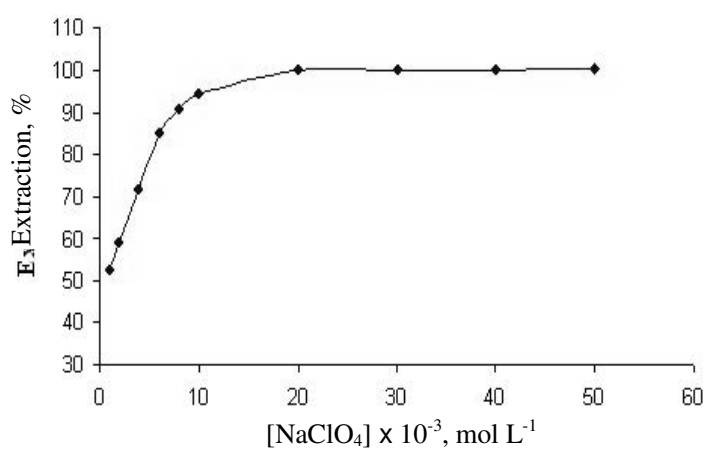

Figure 4. Effect of $\mathrm{ClO}_{4}{ }^{-}$concentration on the extraction of palladium. (Conditions: $P d(I I)$ $50.0 \mathrm{ng} \mathrm{mL}^{-1}$; TMK $5.0 \times 10^{-5} \mathrm{~mol} \mathrm{~L}^{-1} ; \mathrm{CHCl}_{3} 60.0 \mu \mathrm{L} ; \mathrm{TBA}^{+} 2.0 \times 10^{-2} \mathrm{~mol} \mathrm{~L}^{-1}$ and $\mathrm{pH}=3.0$ ).

As can be seen, the extraction of palladium is quantitative above $2.0 \times 10^{-2} \mathrm{~mol} \mathrm{~L}^{-1}$ of $\mathrm{ClO}_{4}^{-}$. Hence, subsequent homogeneous liquid-liquid extraction experiments was carried out with $2.5 \times 10^{-2} \mathrm{~mol} \mathrm{~L}^{-1}$ of $\mathrm{ClO}_{4}^{-}$

\section{Effect of buffer concentration}

The influence of buffer amount on extraction recovery of palladium(II) was investigated by changing concentration of the buffer and keeping other variables constant. It has been found that at buffer's concentration higher that $1.0 \times 10^{-3} \mathrm{~mol} \mathrm{~L}^{-1}$ no significant variations in the extraction yield occurs. Thus, $2.0 \times 10^{-3} \mathrm{~mol} \mathrm{~L}^{-1}$ concentration of buffer solution was chosen as optimal to achieve higher buffer capacity. At concentrations lower than $1.0 \times 10^{-3} \mathrm{~mol} \mathrm{~L}^{-1}$, buffer capacity was insufficient to adjust the $\mathrm{pH}$

\section{Effect of volume of chloroform}

In this extraction method, the concentration factor is strongly dependent on the volume of the sedimented chloroform phase. The relationship among the volume of added chloroform and the concentration factor and extraction efficiency is shown in Figure 5.

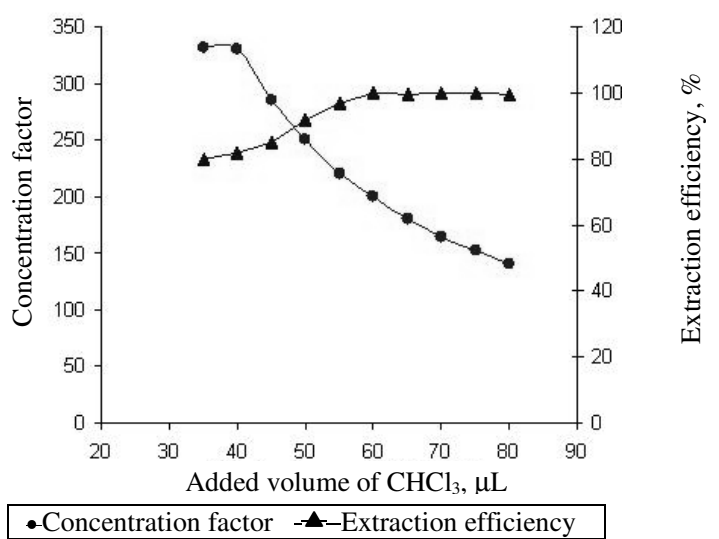

Figure 5. Effect of added volume of chloroform on the extraction of palladium and concentration factor. (Conditions: Pd(II)50.0 $\mathrm{ngmL}^{-1}$; TMK 5.0 $\times 10^{-5} \mathrm{~mol} \mathrm{~L}^{-1}$; $\mathrm{TBA}^{+} 2.0 \times 10^{-2} \mathrm{~mol} \mathrm{~L}^{-1}$; $\mathrm{NaClO}_{4} 2.5 \times 10^{-2} \mathrm{~mol} \mathrm{~L}^{-1}$ and $\mathrm{pH}=3.0$ ). 
As can be seen, the extraction of palladium is quantitative above $60.0 \mu \mathrm{L}$ of $\mathrm{CHCl}_{3}$. Hence, In order to achieve maximum extraction efficiency and concentration factor, $60.0 \mu \mathrm{L}$ of added $\mathrm{CHCl}_{3}$ was selected.

\section{Selectivity of the method for palladium}

For detection interferences, the influence of several ions was tested. The effect of interfering ions at different concentrations on the absorbance of a solution containing $50.0 \mu \mathrm{g} \mathrm{L}^{-1}$ of palladium was studied. An ion was considered to interfere when its presence produced a variation in the absorbance of the sample of more than $5 \%$. This increment of absorbance was evaluated at wavelength $518 \mathrm{~nm}$ (corresponding to maximum absorption of $\mathrm{Pd}$ complex).

Among the interfering ions tested, $\mathrm{Cl}^{-}, \mathrm{I}^{-}, \mathrm{SCN}^{-}, \mathrm{NO}_{3}{ }^{-}, \mathrm{ClO}_{4}^{-}, \mathrm{Li}^{+}, \mathrm{K}^{+}, \mathrm{Na}^{+}, \mathrm{Ba}^{2+}, \mathrm{Ca}^{2+}$, $\mathrm{Mg}^{2+}, \mathrm{Co}^{2+}, \mathrm{Pb}^{2+}, \mathrm{Cd}^{2+}, \mathrm{Al}^{3+}, \mathrm{Ni}^{2+}, \mathrm{Sr}^{2+}, \mathrm{Fe}^{2+}$ (Ion / Pd (II) (w/w) = 1000) and $\mathrm{Ag}^{+}, \mathrm{Fe}^{3+}, \mathrm{Cr}^{3+}$, $\mathrm{Zn}^{2+}, \mathrm{Cd}^{2+}, \mathrm{Cu}^{2+}(\mathrm{Ion} / \mathrm{Pd}(\mathrm{II})(\mathrm{w} / \mathrm{w})=500)$ did not interfere at palladium determination. This is in agreement with the results reported in the literature that TMK is highly selective for palladium at $\mathrm{pH}=3 \pm 0.2^{27}$.

\section{Figures of merit}

Table 1 summarizes the analytical characteristics of the optimized method, including linear range, limit of detection, reproducibility and concentration factor. The limit of detection, defined as $C_{L}=3 S_{B} / m$ (where $C_{L}, S_{B}$ and $m$ are the limit of detection, standard deviation of the blank and slope of the calibration graph, respectively), was $0.4 \mathrm{ng} \mathrm{mL}^{-1}$. The relative standard deviation (RSD) for ten replicate measurements of $20.0 \mathrm{ng} \mathrm{mL}^{-1} \mathrm{Pd}(\mathrm{II})$ was $2.3 \%$.

Table 1. Analytical characteristics of proposed method.

\begin{tabular}{lc}
\hline Parameter & Analytical feature \\
\hline Linear range, $\mathrm{ng} \mathrm{mL}^{-1}$ & $2-100$ \\
Limit of detection, $\mathrm{ng} \mathrm{mL}^{-1}, \mathrm{n}=10$ & 0.4 \\
Repeatability, $\mathrm{RSD}^{\mathrm{a}}, \%, \mathrm{n}=10$ & 2.3 \\
Concentration factor & 10 \\
\hline
\end{tabular}

${ }^{a} \mathrm{Pd}$ (II) concentration was $20.0 \mathrm{ng} \mathrm{mL}^{-1}$ for which RSD was obtained. ${ }^{b}$ Concentration factor is the volume ratio $(\mathrm{Va} / \mathrm{Vs})$ of the aqueous phase (Va) and final volume of sedimented phase (Vs).

The concentration factor (the volume ratio $(\mathrm{Va} / \mathrm{Vs})$ of the aqueous phase $(\mathrm{Va}=10 \mathrm{~mL})$ and final volume of sedimented phase $(\mathrm{Vs}=1.0 \mathrm{~mL})$ after phase separation) was 10 . Certainly a preconcentration factor of $200(50 \mu \mathrm{L}$ of chloroform phase was obtained from $10 \mathrm{~mL}$ of the homogenous aqueous solution) in combination of this method with other techniques that required low volume of sample such as flow injection analysis (FIA) or graphite furnace atomic absorption spectrometry (GF AAS) can be obtained. Preconcentration factor of 200 will make the method very promising for use at sub $\mathrm{ng} \mathrm{mL} \mathrm{m}^{-1}$ level.

\section{Application to samples}

For accessing the capability of the method for real samples with different matrices containing varying amounts of diverse ions, the method was applied to separation, preconcentration and determination of palladium from $10 \mathrm{~mL}$ of water samples. According to the results, the concentration of palladium in analyzed water samples was below the LOD of the method. The suitability of the proposed method for the analysis of natural water samples was checked by spiking samples with 10 and $20 \mu \mathrm{g} \mathrm{L}^{-1}$ of palladium. Good recoveries 
(98-102\%) were achieved for all analyzed samples. The data obtained with the proposed method were presented in Table 2. The results indicate that the proposed method can be reliably used for the determination of palladium in various matrices.

Table 2. Determination of $\mathrm{Pd}(\mathrm{II})$ in different water samples.

\begin{tabular}{|c|c|c|c|}
\hline Sample & $\mathrm{Pd}^{2+}$ spiked, ng $\mathrm{mL}^{-1}$ & $\mathrm{Pd}^{2+}$ detected, ng $\mathrm{mL}^{-1}$ & Recovery, \% \\
\hline \multirow{2}{*}{ Sample $1^{\mathrm{a}}$} & 10.0 & $9.9(2.5)^{\mathrm{f}}$ & 99 \\
\hline & 20.0 & $19.7(2.3)$ & 98.5 \\
\hline \multirow[t]{2}{*}{ Sample $2^{\mathrm{b}}$} & 10.0 & $10.0(2.4)$ & 100 \\
\hline & 20.0 & $19.9(2.2)$ & 99.5 \\
\hline \multirow[t]{3}{*}{ Tap water $^{\mathrm{c}}$} & 0.0 & n.d. & - \\
\hline & 10.0 & $10.1(2.6)$ & 101 \\
\hline & 20.0 & $19.8(2.5)$ & 99 \\
\hline \multirow[t]{3}{*}{ Sea water ${ }^{\mathrm{d}}$} & 0.0 & n.d. & - \\
\hline & 10.0 & $9.8(2.7)$ & 98 \\
\hline & 20.0 & $19.6(2.8)$ & 98 \\
\hline \multirow[t]{3}{*}{ Mineral water ${ }^{\mathrm{e}}$} & 0.0 & n.d. & - \\
\hline & 10.0 & $10.2(2.4)$ & 102 \\
\hline & 20.0 & $20.2(2.5)$ & 101 \\
\hline $\begin{array}{l}\text { able distilled water } \\
\mu g L^{-1} \text { of } K^{+} \text {and } 1 \\
\text { sble distilled water } \\
\text { ug } L^{-1} K^{+} \text {and Lit io } \\
m \text { drinking water s } \\
D \text { of three replicat }\end{array}$ & $\begin{array}{l}\text { iked with } 500 \mu \mathrm{g} L^{-1} \text { o } \\
\text { ions } \\
\text { iked with } 250 \mu \mathrm{g} L^{-1} \text { of } \\
\text { tem of Tehran. }{ }^{d} \text { Caspi } \\
\text { xperiments, n.d. = Not }\end{array}$ & $\begin{array}{l}\mathrm{U}^{2+}, \mathrm{Co}^{2+}, \mathrm{Cd}^{2+}, \mathrm{Fe}^{3+}, \mathrm{Ni}^{2} \\
+\mathrm{Co}^{2+}, \mathrm{Cd}^{2+}, \mathrm{Fe}^{3+}, \mathrm{Ni}^{2+} \mathrm{a} \\
\text { sea water. }{ }^{e} \mathrm{From} \mathrm{Abali} \\
\text { tected. }\end{array}$ & $\begin{array}{l}\text { and } \mathrm{Cr}^{3+} \text { and } \\
\mathrm{Cr}^{3+} \text { and } \\
\text { ineral water. }\end{array}$ \\
\hline
\end{tabular}

\section{Conclusions}

In this work, we used a homogenous liquid-liquid extraction method for separation and determination of palladium that utilizes an ion-pair formation of $\mathrm{TBA}^{+}$and $\mathrm{ClO}_{4}{ }^{-}$for phase separation phenomenon (a $\mathrm{pH}$ independent phase separation) from the homogeneous solution. This method is simple, rapid, highly selective and sensitive. High preconcentration factor can be obtained easily by this method. The proposed method can be applied to environmental and / or other sample having Pd levels higher than the detection limit of the method.

\section{Acknowledgement}

The author thanks the research council at the University of Tehran and Iran University of Science and Technology for financial support.

\section{References}

$1 \quad$ Kezler D A and Ibers J A, Inorg Chem., 1983, 22, 3366.

2. Bruzzoniti M C, Mucchino C, Tarasco E and Sarzanini C, J Chromatogr A., 2003, 1007, 93.

3. Lee S D, Biochemical Aspects of Environmental pollutants, Ann Arbor Science Publisher, Ann Arbor, MI, 1980.

4. Ensafi A A and Eskandari H, Microchem J., 1999, 63, 266.

5. Alizadeh N, Salimi S, Anal Sci., 2002, 18, 307.

6. Reddy B K, Reddy K J, Kumar J R, Kumar A K and Reddy A V, Anal Sci., 2004, 20, 925. 
7. Kovalev I A, Bogacheva L V, Tysin G I, Formanovsky A A and Zolotov Y A, Talanta, 2000, 52, 39.

8. Iglesias M, Antico E and Salvado V, Talanta, 2003, 59, 651.

9. Di P, Davey D E, Talanta, 1995, 42,685.

10. Tokalioglu S, Oymak T and Kartal S, Anal Chim Acta, 2004, 511, 255.

11. Farhadi K and Teimori G, Talanta, 2005, 65, 925.

12. Liu P, Su Z, Wu X and Pu Q, J Anal At Spectrom., 2002, 17, 125.

13. Ohta K, Ogawa J and Mizuno T, J Anal Chem., 1997, 357, 995.

14. Beinrohr E, Lee M L, Tschopel P and Tolg G, Fresenius J Anal Chem., 1993, 346, 689.

15. Van Loon J C and Barefoot R R, Determination of the Precious Metals Selected Instrumental Methos, John Wiley and Sons, Chichester, 1991.

16. Borges D L G, Silva da veiga M A M, Fresoura V L A, Welz B and Curtius A J, $J$ Anal At Spectrom., 2003, 18, 501.

17. Takagai Y and Igarashi S, Am Lab News, 2000, 34, 29.

18. Murata K, Yokoyana Y and Ikada S, Anal Chem., 1972, 44, 805.

19. Matkovich C E and Chisian G D, Anal Chem., 1973, 45, 1915.

20. Igarashi S, Arai T and Kawakami T A, Bunseki kagaku., 1994, 43, 1183.

21. Igarashi S, Ide N and Takagai Y, Anal Chim Acta, 2000, 424, 263.

22. Ghiasvand A R, Shadabi S, Mohagheghzadeh E and Hashemi P, Talanta, 2005, 66, 912.

23. Takagai Y, Maekoya C and Igarashi S, Nippon Kaguka Karishi, 2000, 4, 291.

24. Igarashi S, Ide N, Takahata K and Takagai Y, Bunseki Kagaku., 1999, 48, 1115.

25. Oshite S and Igarashi S, Anal Sci., 2001, 17, i1329.

26. Jamali M R, Assadi Y and Shemirani F, Sep Sci Technol., 2007, 42, 3503.

27. Marczenko Z, Separation and Spectrophotometric Determination of Elements, Masson M, Eds., John Wiley \& Sons, New York, 1986. 


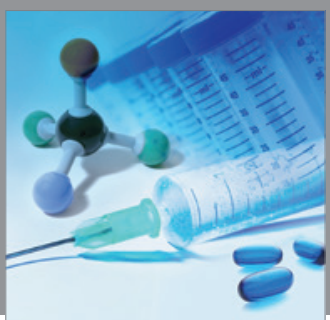

International Journal of

Medicinal Chemistry

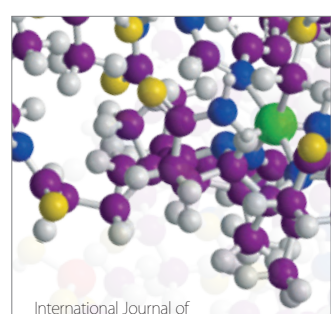

Carbohydrate Chemistry

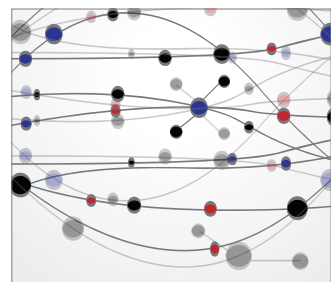

The Scientific World Journal
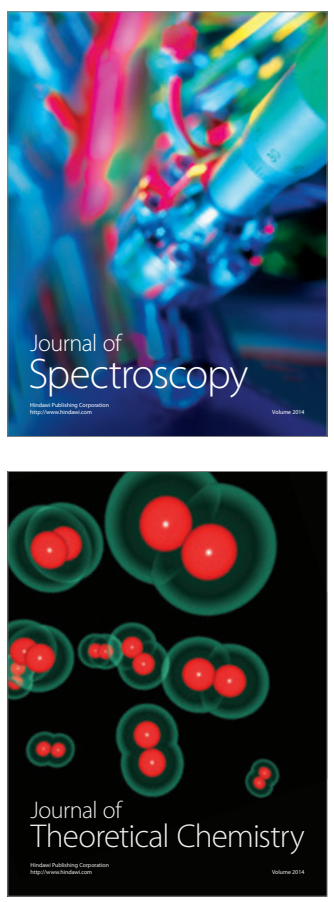
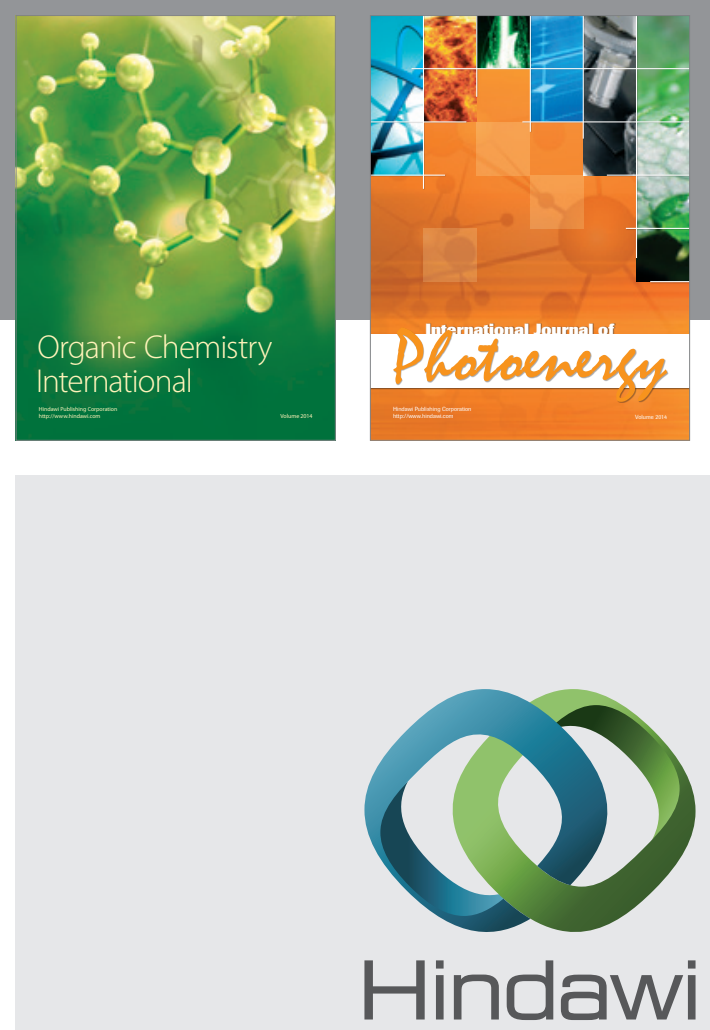

Submit your manuscripts at

http://www.hindawi.com
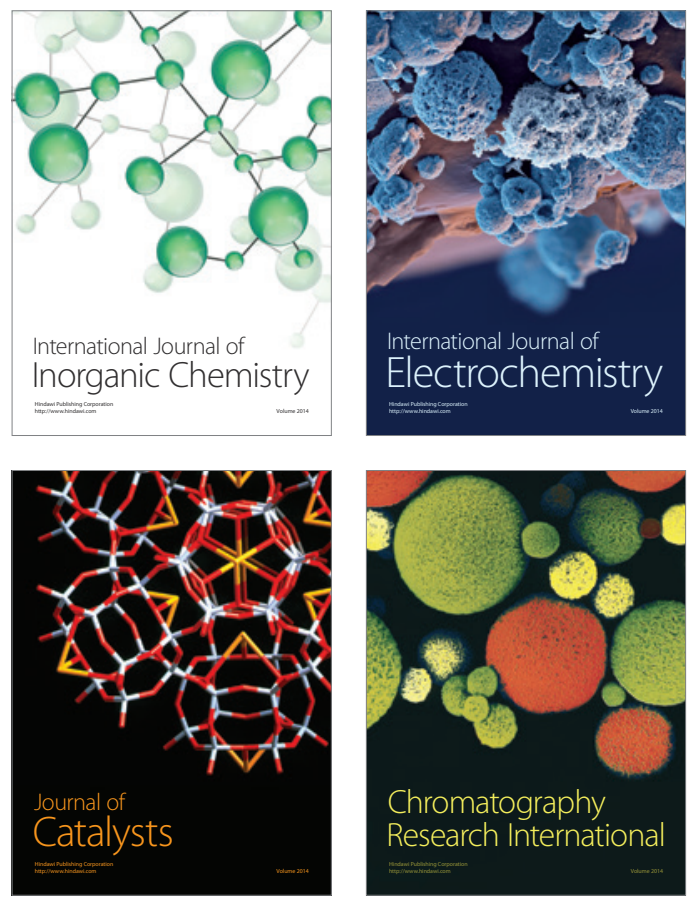
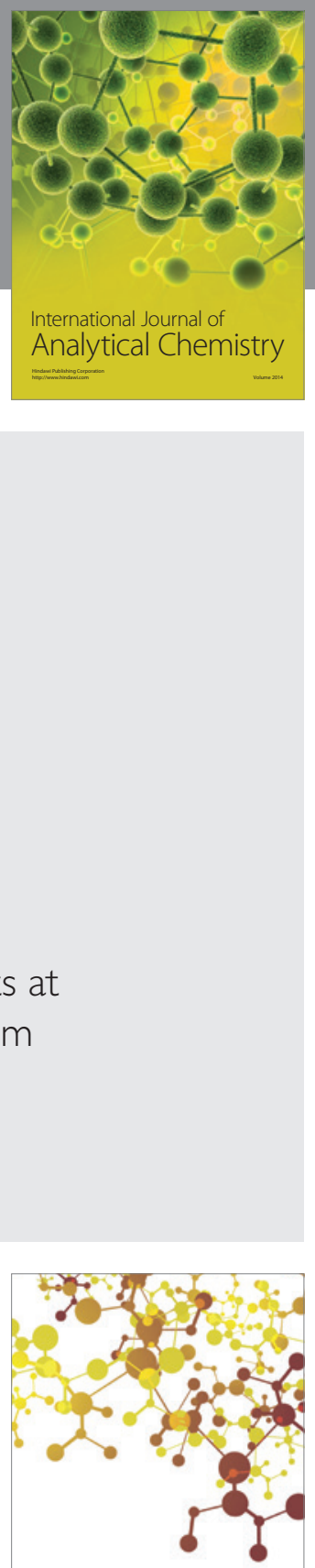

Journal of

Applied Chemistry
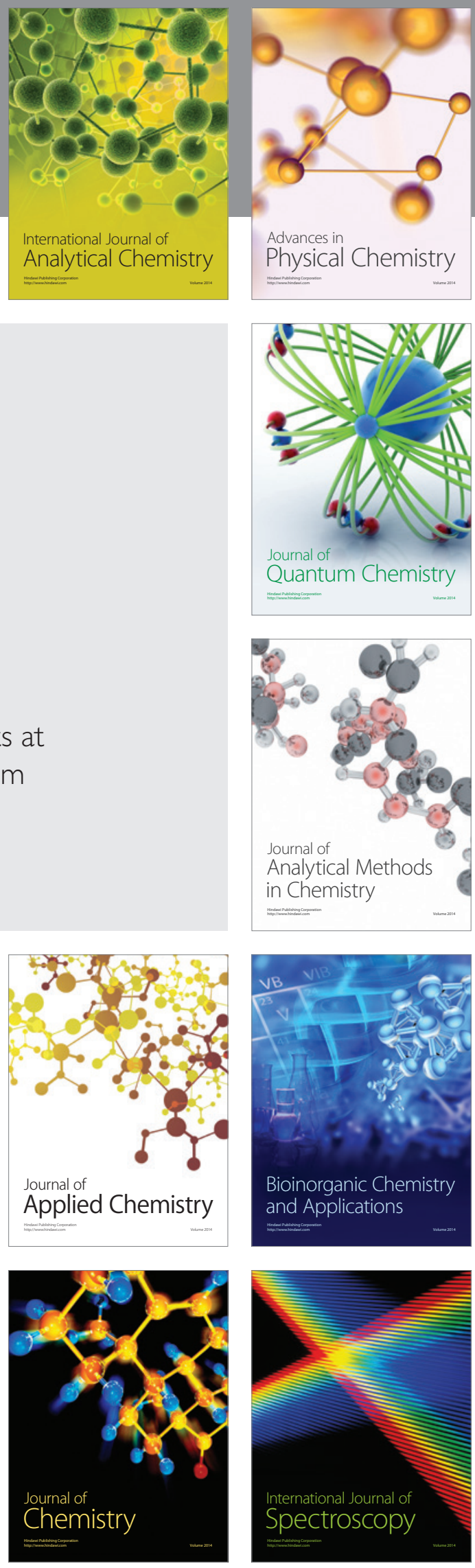